\title{
Liberalization, Moral Hazard in Banking, and Prudential Regulation: Are Capital Requirements Enough?
}

\author{
By Thomas F. Hellmann, Kevin C. Murdock, and Joseph E. Stiglitz*
}

\begin{abstract}
In a dynamic model of moral hazard, competition can undermine prudent bank behavior. While capital-requirement regulation can induce prudent behavior, the policy yields Pareto-inefficient outcomes. Capital requirements reduce gambling incentives by putting bank equity at risk. However, they also have a perverse effect of harming banks' franchise values, thus encouraging gambling. Pareto-efficient outcomes can be achieved by adding deposit-rate controls as a regulatory instrument, since they facilitate prudent investment by increasing franchise values. Even if deposit-rate ceilings are not binding on the equilibrium path, they may be useful in deterring gambling off the equilibrium path. (JEL G2, E4, L5)
\end{abstract}

Banking crises are pervasive. In the last two decades, the frequency of severe banking crises has increased significantly. Banking crises are important not just because of the devastation that they bring to one particular sector of the economy, but because typically the shock waves affect the entire economy. In the nineteenth century, most of the U.S. economy's economic downturns were related to financial panics. The budgetary consequences for governments, which often bear a significant part of the costs of the bailout, cannot be ignored either. A compilation of cases over the past two decades by the World Bank shows costs ranging up to 40 percent of GDP. Probably the best known examples are the savings and loan

\footnotetext{
* Hellmann: Graduate School of Business, Stanford University, Stanford, CA 94305; Murdock: Graduate School of Business, Stanford University, Stanford, CA 94305, and McKinsey \& Company, 21 South Clark Street, Chicago, IL 60603; Stiglitz: The World Bank, 1818 H Street, NW, Washington, DC 20433, and on leave from the Department of Economics, Stanford University, Stanford, CA 94305. We thank Masahiko Aoki, Sudipto Bhattacharya, Jerry Caprio, Serdar Dinç, John Roberts, Paul Romer, two anonymous referees, and seminar participants at the Federal Reserve Bank of New York, the University of Mannheim, Stanford University Department of Economics and Graduate School of Business, the William Davidson Institute at the University of Michigan, and the World Bank. Any remaining errors are ours. This paper represents the views of the authors and does not necessarily represent that of any organization with which they are or have been affiliated.
}

(S\&L) crisis in the United States, which resulted in estimated losses of $\$ 180$ billion or 3.2 percent of GDP, and the ongoing banking crisis in Japan, where some estimates of nonperforming loans approach 25 percent of GDP. ${ }^{1}$

Prudential regulation is meant to protect the banking system from these problems. Traditionally, it has consisted of a mixture of monitoring individual transactions (ensuring, for instance, that adequate collateral was put up), regulations concerning self-dealing, capital requirements, and entry restrictions. In some countries, restrictions were placed on lending in particular areas: many East Asian countries, for example, used to have restrictions on real estate lending. ${ }^{2}$ Finally, many countries imposed interest-rate restrictions. ${ }^{3}$ Concerns about bank runs also led many countries to provide deposit insurance and to

\footnotetext{
${ }^{1}$ Typically, recovery rates on nonperforming loans are less than 50 percent. If this holds true for Japan, losses could exceed 10 percent of GDP.

${ }^{2}$ The intent of these restrictions was only partially to enhance the safety and soundness of the banking system; these restrictions were also intended to direct credit toward what were viewed at the time as more productive investments.

${ }^{3}$ Interest-rate restrictions, like many of the other restrictions, served several other objectives; low interest rates had significant positive effects on government budgets in periods in which the debt GDP ratio was high, such as after World War II. We discuss this in Hellmann and Murdock (1997) and Hellmann et al. (1997, 1998a).
} 
establish central banks to serve as lenders of last resort.

Over the past decade, several changes in the systems of prudential regulation have occurred. First, given the increased number and complexity of transactions, there has been greater emphasis on monitoring banks' risk-management systems, and less emphasis on monitoring individual transactions. Second, in a wave of financial-market liberalization, interest rates have been deregulated, and restrictions on the asset choices of banks have been lifted. Third, greater emphasis has been placed on capital requirements, typically using the Bank of International Settlements (BIS) standards of the Basle Accord.

As these changes have occurred, financial crises have become more frequent (see Gerard Caprio, Jr. and Daniela Klingebiel, 1997; Klaus P. Fischer and Martin Chénard, 1997). Most observers agree that moral hazard plays an important role in these failures. Edward Kane (1989) and Rebel A. Cole et al. (1995) document the problem of "gambling on resurrection": banks choose a risky asset portfolio that pays out high profits or bonuses if the gamble succeeds but leaves depositors, or their insurers, with the losses if the gamble fails. ${ }^{4}$ It has been suggested that deposit insurance is the problem, since it reduces the incentives for depositors to monitor. ${ }^{5}$ Others have argued that it makes little difference whether countries have a formal system of deposit insurance since, in the event of a financial crisis, there will be a bailout. ${ }^{6}$ Moreover, the fact that there have been financial crises in countries with and without formal deposit-insurance systems suggests that eliminating formal deposit insurance by itself does not solve the problem.

\footnotetext{
${ }^{4}$ George A. Akerlof and Paul M. Romer (1993) further elaborate on the moral hazard, arguing that banks may use fraudulent lending practices (such as insider lending) to "loot" banks. In this case bank managers extract value out of the banks even if this leads to insolvency.

${ }^{5}$ One may question, however, both the efficacy and desirability of depositor monitoring, given that monitoring is a public good. See Stiglitz $(1985,1992,1994)$ and the discussion in our working paper (Hellmann et al., 1998b).

${ }^{6}$ As one commentator quipped, there are two kinds of countries: those that have deposit insurance, and those that don't yet know that they have it.
}

This paper asks whether financial liberalization itself could be part of the problem. Some recent empirical studies suggest it may be: large interest-rate increases, which are associated with financial-market liberalization, are also systematically related to financial crises (see Asli Demirgüç-Kunt and Enrica Detragiache, 1997, 1998). This paper approaches the question from a theoretical perspective. Financialmarket liberalization increases competition; competition erodes profits; lower profits imply lower franchise values (i.e., the capitalized value of expected future profits); and lower franchise values lower incentives for making good loans, increasing the moral-hazard problem. With sufficient competition banks will find it desirable to gamble. There is thus an inconsistency of interest-rate liberalization and prudential bank behavior.

We ask whether an increase in capital requirements can offset the adverse effects of liberalization. If banks hold sufficient capital, they internalize the adverse consequences of gambling and thus will choose to invest prudently. While it is possible to combat moral hazard with capital requirements, we find that banks must be forced to hold an inefficiently high amount of capital. It is impossible to implement any Pareto-efficient outcome using just capital requirements as the tool of prudential regulation. That is, freely determined deposit rates are inconsistent with Pareto efficiency.

We then ask whether there is any way to implement outcomes along the Pareto frontier. The reason why capital requirements alone are insufficient is because, with freely determined deposit rates, banks have excessive incentive to compete for deposits by offering higher rates. Capital requirements only become effective when they raise banks' costs sufficiently to impact the banks' willingness to pay out high deposit rates. But if capital requirements are an indirect way of lowering deposit rates, why not control deposit rates in the first place? Indeed, we show that any Pareto-efficient outcome can be implemented by a combination of depositrate controls and capital requirements.

The benefit of deposit-rate controls for promoting stability in the banking sector seems to have been intuitively understood by regulators. In discussing the "Temporary Interest Rate Ad- 
justment Law" of 1947, which regulated Japanese deposit rates, Yoshio Suzuki (1987 p. 41) notes:

Of course, the purpose of this law was to prevent interest rate competition that was destructive to the profitability of financial institutions. That is, the law aimed more at ensuring stable business condition for financial institutions through external controls on competition than at ensuring prudent management of such institutions based on internal controls.

Similarly, in the United States one of the main regulatory changes preceding the $\mathrm{S} \& \mathrm{~L}$ crisis was the abolition of regulation Q, which had imposed deposit-rate controls. Michael C. Keeley (1990) finds a direct relationship among reforms that increased competition, the reduction in franchise value of banks, and an increase in the number of bank failures during the 1980's in the United States.

One view of the recent financial crises in East Asia and the weakened financial system in Japan is that the problems arose at least in part as a result of financial-market liberalization. ${ }^{7}$ First, financial-market liberalization reduced barriers to entry and increased competition: more foreign banks were allowed in the country; restrictions on opening branches were reduced; and where there were deposit-rate ceilings, these were either eliminated or reduced. All these reduced profitability and thus franchise value of existing domestic banks. Second, other aspects of the liberalization agenda reduced restrictions imposed on banks. A range of new activities that had previously been precluded, such as many derivative trades and foreign currency transactions, opened up many new ways for banks to engage in gambling activities. Moreover, restrictions on real estate lending were eliminated. ${ }^{8}$ Third, at the same time that finan-

\footnotetext{
${ }^{7}$ For further discussion on the dynamics underlying the crises in East Asia in 1997, see Steven Radelet and Jeffrey D. Sachs (1998) and James Tobin (1998).

${ }^{8}$ Real estate lending expands the opportunity for excessive risk taking. This is because there may be great volatility in the underlying land prices. To the extent that it is difficult to ascertain the market value of real estate assets, financial institutions can also obfuscate the value of their capital
}

cial liberalization undermined franchise value and opened up new gambling opportunities, few compensatory actions were taken to strengthen regulatory oversight. Capital requirements were not increased, and other instruments of prudential control were eliminated. The capabilities of the agencies in charge of regulatory oversight were not upgraded, and in fact, they frequently declined. ${ }^{9}$

In our model we examine the moral-hazard problem of banks in a dynamic setting. Banks can either invest in a prudent asset yielding high expected returns or in an inefficient gambling asset that can yield high private returns for the bank if the gamble pays off but imposes costs on depositors if the gamble fails. If markets are sufficiently competitive, the bank earns relatively little from prudent investment, but the bank can always capture a one-period rent from gambling. Thus increased competition tends to promote gambling in the banking sector.

Some form of prudential regulation is then necessary to induce banks to invest prudently. Capital requirements force banks to have more of their own capital at risk so that they internalize the inefficiency of gambling. Clearly, once banks have enough of their own capital invested, banks can be induced to invest in the prudent asset. This paper develops an alternative form of prudential regulation: the use of deposit-rate ceilings to create franchise value for banks. Franchise value is the discounted stream of future profits for the bank, a value that can only be captured if the banks stays in operation. If the bank gambles and fails, it loses its franchise value. Franchise value acts as intangible capital, which can be a substitute for tangible capital. If a bank has sufficient franchise value, it will choose to invest in the prudent asset.

Given two potentially effective forms of

(particularly when banks do not mark to market) because banks can sell assets that have increased in value but hold on to assets that have decreased in value.

${ }^{9}$ For example in Thailand (and elsewhere too) the rapid increases in salaries in the private sector, combined with fiscal constraints on public authorities, led to a mismatch between public and private salaries, and the central banks and government lost many of their most talented people to the private sector. 
prudential regulation, this paper seeks to determine the optimal form of prudential regulation. The Pareto frontier is given by the lowest level of capital for each level of deposit rates, which is consistent with the bank's choosing to invest in the prudent asset.

To see why it impossible to have a Paretoefficient equilibrium where banks freely determine deposit rates, consider the incentives of a bank where all of its competitors are choosing to offer the Pareto-efficient deposit rate. Along the Pareto frontier, the bank is exactly indifferent between gambling and the prudent asset (i.e., the total profits that the bank earns on a fixed amount of deposits are identical). Then, it must be the case that the bank earns a higher expected margin on the gambling asset than on the prudent asset because, when the bank gambles, it will forfeit its franchise value should the gamble fail. If this bank offered the same deposit rate as its competitors, it would invest in the prudent asset and get its market share. If, however, the bank were to offer a slightly higher deposit rate, it would capture additional deposits, upon which it could earn a higher margin if it were to gamble. Because of the market-stealing effect, each individual bank has an incentive to defect from any candidate equilibrium along the Pareto frontier. We thus find that freely determined deposit rates are inconsistent with Pareto efficiency.

The response that this paper focuses on is the use of deposit-rate controls to create franchise value. Deposit-rate ceilings effectively combat this market-stealing effect by precluding banks from competing through inefficiently high deposit rates. We show that, with an appropriate ceiling in place, all Pareto-efficient outcomes can be implemented.

Our results suggest that there is a clear theoretical connection between liberalization and the degree of the moral-hazard problem. We find that freely determined deposit rates are inconsistent with Pareto efficiency. Banks offer inefficiently high deposit rates in an effort to steal share from their rivals. Liberalization usually has a stated goal of increasing competition in the financial sector. This will have the effect of increasing the interbank elasticity of deposits while having a more modest, if any, effect on the total elasticity of deposits. This increase in the interbank elasticity will increase marketstealing incentives, and this creates the link between liberalization and financial crises.

Of course, the policy we study in detail in this paper (deposit-rate ceilings) is not the only policy that could be used to generate improvements over using capital requirements alone. Other policy instruments that the government could apply include asset-class restrictions, entry restrictions, and enhancing direct supervision. The goal of each of these policies is either to limit the scope of the bank's ability to engage in moral-hazard behavior or to increase the positive incentives of the bank to invest prudently. Determining the optimal application of all of these policies is beyond the scope of this paper; the point of the paper is first to show the inadequacy of capital requirements alone, and second to identify the potential value of including deposit-rate ceilings as an instrument of prudential regulation.

We discuss some of these broader policy issues in previous work (Hellmann et al., 1996, 1997, 1998a; Hellmann and Murdock, 1997). In those papers, we consider a framework of financialmarket regulation. We propose a set of policies that we term "financial restraint," which we distinguish from financial repression. An important difference is that with financial restraint, interest-rate controls are used to improve the efficiency of private financial markets (as shown in the current paper), whereas with financial repression, interest rates are typically a mechanism for the government to extract rents from the private sector.

The theoretical model builds on the work of Sudipto Bhattacharya (1982), which noted the usefulness of deposit-rate controls in a simple static model. ${ }^{10}$ Caprio and Lawrence H. Summers (1996) emphasize the importance of franchise value for prudential regulation. ${ }^{11}$ The analysis of capital requirements is related to Jean-Claude Rochet (1992), who explains how

\footnotetext{
${ }^{10}$ Bruce D. Smith (1984) also has a model where depositrate controls reduce the likelihood of financial instability. In his model deposit-rate controls eliminate an instability problem à la Michael Rothschild and Stiglitz (1976).

${ }^{11}$ Keeley (1990), Steven R. Weisbrod et al. (1992), and Rebecca S. Demsetz et al. (1996) provide empirical evidence from the United States and Japan.
} 
capital requirements affect the incentives for gambling. ${ }^{12}$ In the analysis, we abstract from some of the other criticism of capital requirements, such as the fact that they fail to recognize all relevant risk (see Mathias Dewatripont and Jean Tirole [1994] for a more comprehensive treatment). ${ }^{13}$

The remainder of this paper is organized as follows: In Section I, the model is introduced. We then examine competitive equilibria and develop conditions under which gambling occurs in equilibrium in Section II. Section III develops the instruments of prudential regulation and highlights the trade-offs between using capital requirements and deposit-rate controls. Section IV introduces the distinction between binding and nonbinding deposit-rate controls and shows how nonbinding ceilings can limit the equilibrium-path behavior by gambling banks to promote prudent outcomes. In Section V, we consider how introducing endogenous rates of return creates feedback effects that strengthen our conclusions from the basic model. Concluding remarks follow in Section VI.

\section{The Model}

Consider a bank that operates for $T$ periods. In each period, the bank offers an interest rate on deposits of $r_{i}$ in competition with other banks which offer depositors interest rates $r_{-i}$. The total volume of deposits mobilized by the bank is $D\left(r_{i}, r_{-i}\right)$, with the volume of deposits increasing in the bank's own interest rate and decreasing in the competitors' rate $\left(D_{1}>0\right.$, $\left.D_{2}<0\right){ }^{14}$

Depositors have deposit insurance, so the volume of deposits depends only on the interest

\footnotetext{
${ }^{12}$ Note, however, that Chun H. Lam and Andrew H. Chen (1985), Gerard Genotte and David Pyle (1991), and David Besanko and George Katanas (1996) show that, in some circumstances, capital requirements may actually increase the portfolio risk.

${ }^{13}$ Criticisms include that (i) they induce rigidities in the adjustment process; (ii) they typically are implemented by examining risk on an asset-by-asset basis, ignoring correlations; and (iii) they often focus on credit risk, ignoring market risks.

${ }^{14}$ The only additional assumption on the demand function is that it satisfies concavity of the bank's value function.
}

rates offered. ${ }^{15}$ In our judgment, the assumption of deposit insurance best reflects reality. Note, however, that our results do not depend on this assumption. In our working paper version (Hellmann et al., 1998b), we show that all of our qualitative results continue to hold in an environment without deposit insurance.

After funds have been raised, the bank allocates its assets, wherein the bank faces a moralhazard problem in choosing its loan portfolio. For simplicity, we assume that the bank may choose between two assets: the prudent asset, yielding a return $\alpha$; and the gambling asset, yielding a return of $\gamma$ with probability $\theta$ and $\beta$ with probability $1-\theta$. The prudent asset has higher expected return $(\alpha>\theta \gamma+(1-\theta) \beta)$, but if the gamble succeeds the bank earns higher private return $(\gamma>\alpha)$. The bank invests both the deposits it mobilizes and its own capital $k$, which is expressed as a percentage of the deposits mobilized so that the total assets invested equal $(1+k) D\left(r_{i}, r_{-i}\right)$.

The opportunity cost of that capital is $\rho .{ }^{16} \mathrm{In}$ this section we assume that $\rho$ is exogenous and that $\rho>\alpha$ (i.e., bank capital is costly). A simple revealed-preference argument suggests that the case of $\rho>\alpha$ is the relevant one. If capital truly had no opportunity cost, then the problem of moral hazard in banking would not be so prevalent as it remains today, because regulators would simply ensure that banks hold sufficient capital to induce prudent investment, and banks would willingly comply. In Section V we develop this argument further. We examine an extension of the model where $\rho$ is determined endogenously as the equilibrium rate of return that clears the market for bank equity capital. Without capital requirements capital is not costly (i.e., $\rho=\alpha$ ), but banks will typically hold either too little capital or none at all. A binding

\footnotetext{
${ }^{15}$ We do not explicitly model the fees paid by banks for deposit insurance, although our results hold for any fixed fee for insurance. Yuk-Shee Chan et al. (1992) and Ronald Gianmarino et al. (1993) show how more sophisticated fee schemes can be used to reduce moral hazard.

${ }^{16}$ We can think of the cost of capital as the dilution cost to the owners. Equity investors know the expected returns of the bank in every period (which may depend on whether the bank will gamble or not, which outside equity investors can rationally anticipate). They will provide capital if the expected return on investment equals their opportunity $\operatorname{cost} \rho$.
} 
capital requirement, however, increases the demand for capital, endogenously making capital costly (i.e., $\rho>\alpha$ ). ${ }^{17}$

Banks are subject to prudential regulation by the government. At the end of each period, the regulator inspects the balance sheet of all banks. If a bank has negative equity (i.e., the bank cannot repay all its depositors in full), its franchise is revoked. Thus, if a bank were to gamble and the gamble fails, then the bank will lose its franchise and cease operation. ${ }^{18}$ In this economy with an (ex post) perfectly informed regulator there are no "zombie" banks "gambling on their resurrection" (see Kane, 1989) that have negative equity and are hoping that a successful gamble will return them to solvency. The regulator, however, cannot perfectly monitor the $e x$ ante investment portfolio of the bank. This is consistent with the shift in regulator structure to monitoring the risk-management system of the bank rather than examining each individual financial transaction.

The per-period profits of the bank when it chooses the prudent asset are $\pi_{\mathrm{P}}\left(r_{i}, r_{-i}, k\right)=$ $m_{\mathrm{P}}\left(r_{i}, k\right) D\left(r_{i}, r_{-i}\right)$, where $m_{\mathrm{P}}\left(r_{i}, k\right)=\alpha(1+$ $k)-\rho k-r_{i}$ is the effective profit margin that the bank earns on each unit of deposit, net of its cost of capital. When the bank gambles, perperiod profits are $\pi_{\mathrm{G}}\left(r_{i}, r_{-i}, k\right)=m_{\mathrm{G}}\left(r_{i}\right.$, k) $D\left(r_{i}, r_{-i}\right)$, where $m_{\mathrm{G}}\left(r_{i}, k\right)=\theta(\gamma(1+$ $\left.k)-r_{i}\right)-\rho k$. The gambling margin depends on whether the gamble is successful. If so, then the bank captures a high return on assets and repays its depositors. If the gamble fails, then the bank is closed down by the regulator.

Banks maximize their expected discounted profits, $V=\sum_{t=0}^{T} \delta^{t} \pi_{t}$. Following Douglas W. Diamond (1989) we will look at the limit as $T \rightarrow$ $\infty$. Banks will thus choose strategies corre-

\footnotetext{
${ }^{17}$ Gary Gorton and Andrew Winton (1997) also derive that bank capital is costly endogenously in a generalequilibrium model.

${ }^{18}$ This assumes that the return earned by the bank when the gamble fails is insufficient to repay depositors. It is straightforward to show that this assumption is always satisfied when a bank chooses to gamble in equilibrium because the gambling asset has a lower expected return than the prudent asset. It is only when the bank can impose a cost on depositors (or, more specifically, the deposit insurer) that the private expected return to the bank is higher from gambling.
}

sponding to the infinitely repeated static Nash equilibrium.

The timing of the stage game works as follows: Banks simultaneously choose their own level of capital and offer a deposit rate. Depositors then choose the bank in which to place their funds. Banks then choose their asset portfolio. Finally, returns are realized, and the regulator inspects the balance sheet of the bank. ${ }^{19}$

\section{Competitive Equilibria with Gambling}

Before comparing different forms of prudential regulation, it is worthwhile to determine whether any regulation is indeed necessary. In particular, the purpose of this section is to determine conditions under which banks would choose to gamble in equilibrium. The expected return from the prudent asset is $V_{\mathrm{P}}\left(r_{i}, r_{-i}\right.$, $k)=\pi_{\mathrm{P}}\left(r_{i}, r_{-i}, k\right) /(1-\delta)$, while the expected return from the gambling asset is $V_{\mathrm{G}}\left(r_{i}\right.$, $\left.r_{-i}, k\right)=\pi_{\mathrm{G}}\left(r_{i}, r_{-i}, k\right) /(1-\delta \theta)$. The investment process by banks occurs in two stages: the deposit mobilization stage and the assetallocation stage. At the allocation stage, banks have $D\left(r, r_{-i}\right)$ units of deposits to invest with an interest-rate cost of $r$. Banks will choose to invest in the prudent asset if $V_{\mathrm{P}}\left(r, r_{-i}, k\right) \geq$ $V_{\mathrm{G}}\left(r, r_{-i}, k\right)$, and they will invest in the gambling asset otherwise. From this relationship, we can develop a "no-gambling condition" which determines the threshold interest rate at which gambling will occur, namely,

$$
\begin{gathered}
\pi_{\mathrm{G}}\left(r, r_{-i}, k\right)-\pi_{\mathrm{P}}\left(r, r_{-i}, k\right) \\
\leq(1-\theta) \delta V_{\mathrm{P}}\left(r, r_{-i}, k\right) .
\end{gathered}
$$

This constraint is intuitive. The one-period rent $\left(\pi_{\mathrm{G}}-\pi_{\mathrm{P}}\right)$ that the bank expects to earn from

\footnotetext{
${ }^{19}$ We should note that our model has a static structure within each investment period. There is a growing literature of papers (Charles W. Calomiris and Charles M. Kahn, 1991; Mark J. Flannery, 1994) that has a richer dynamic structure within each investment period. This matters most in a world without deposit insurance, where one would want to analyze the role of demand deposits and the potential disciplinary role of the interim withdrawal by depositors. This literature generally finds that interim monitoring by demand depositors can mitigate but not fully eliminate problems of moral hazard.
} 
gambling must be less than the lost franchise value $\left(\delta V_{\mathrm{P}}\right)$ that the bank gives up if the gamble fails (with probability $1-\theta$ ). From this we can determine the critical deposit interest rate, $\hat{r}(k)$, such that for $r \leq \hat{r}(k)$ the bank will choose to invest in the prudent asset (assuming a symmetric equilibrium in deposit rates):

$$
\begin{aligned}
\hat{r}(k)= & (1-\delta)\left(\frac{\alpha-\theta \gamma}{1-\theta}\right)(1+k) \\
& +\delta[\alpha(1+k)-\rho k] .
\end{aligned}
$$

When the bank is farsighted (as $\delta \rightarrow 1$ ), the bank can pay out a deposit interest rate that approaches the bank's net return on assets $(\alpha[1+k]-\rho k)$ and still choose to invest in the prudent asset. This is sensible because as $\delta \rightarrow 1$ the bank only cares about average perperiod returns, so the bank would never engage in a gambling activity that returns a finite positive one-period rent at the risk of losing all future returns. Once the bank is less than perfectly farsighted, however, the bank must earn a sufficiently large positive profit each period so that its franchise value at risk is greater than the expected returns from gambling. ${ }^{20}$

Given the bank's asset-allocation decision, we can turn to how banks compete in the market for deposits. We will assume that, if a competitive equilibrium with no gambling exists, then that is the equilibrium that will be selected by the banks. If a bank intends to invest in the prudent asset, then it will choose

$$
\left(r_{\mathrm{P}}, k_{\mathrm{P}}\right)=\arg \max _{r, k}\left\{V_{\mathrm{P}}\left(r, r_{-i}, k\right)\right\} .
$$

For a symmetric equilibrium (i.e., $r_{-i}=r_{\mathrm{P}}$ ), using the first-order condition $\left(\partial V_{\mathrm{P}} / \partial r_{i}=0\right)$, we have

$$
m_{\mathrm{P}}\left(r_{\mathrm{P}}, k\right)=D\left(r_{\mathrm{P}}, r_{\mathrm{P}}\right) /\left(\partial D\left(r_{\mathrm{P}}, r_{\mathrm{P}}\right) / \partial r_{i}\right)
$$

which implicitly defines $r_{\mathrm{P}}(k)$. Using $\varepsilon \equiv(\partial D /$ $\left.\partial r_{i}\right)(r / D)$, we have

\footnotetext{
${ }^{20}$ The remaining comparative statics on the no-gambling condition are immediate: $\partial \hat{r} / \partial \alpha>0, \partial \hat{r} / \partial \gamma<0, \partial \hat{r} / \partial \theta<$ 0 . The no-gambling condition becomes less stringent as the prudent asset is more attractive, and more stringent as the gambling asset is more attractive.
}

$$
r_{\mathrm{P}}(k)=[\alpha(1+k)-\rho k] \varepsilon /(\varepsilon+1) .
$$

Because $\partial V_{\mathrm{P}} / \partial k=-(\rho-\alpha) D\left(r, r_{-i}\right) /(1-$ $\delta)<0$, increasing a bank's capital only reduces the bank's expected profits, and so the bank will choose to minimize its own capital that it invests. Thus, in the competitive equilibrium, if the bank were to choose the prudent asset, then $r_{\mathrm{P}}(0)=\alpha \varepsilon /(\varepsilon+1)$. As competition for deposits becomes sufficiently intense (i.e., as $\varepsilon \rightarrow \infty$ ), then the competitive deposit rate approaches $\alpha$, with the result that the franchise value of the bank becomes arbitrarily small. But as discussed above, once the deposit rate exceeds a critical threshold $\left[r_{\mathrm{P}}(k)>\hat{r}(k)\right]$, the bank earns greater expected returns from gambling than from investing in the prudent asset, and thus no equilibrium where all banks choose to invest in the prudent asset can exist.

If we turn our attention to the case where the bank invests in the gambling asset, we can repeat the preceding logic to show that

$$
m_{\mathrm{G}}\left(r_{\mathrm{G}}, k\right)=\theta D\left(r_{\mathrm{G}}, r_{\mathrm{G}}\right) /\left(\partial D\left(r_{\mathrm{G}}, r_{\mathrm{G}}\right) / \partial r_{i}\right)
$$

implying that

$$
r_{\mathrm{G}}(k)=[\gamma(1+k)-(\rho k / \theta)] \varepsilon /(\varepsilon+1) .
$$

As above,

$$
\partial V_{\mathrm{G}} / \partial k=-(\rho-\theta \gamma) D\left(r, r_{-i}\right) /(1-\delta \theta)<0
$$

so no bank would voluntarily hold capital.

The above argument is summarized in the following proposition. Let $\bar{\varepsilon} \equiv \hat{r}(0) /[\alpha-$ $\hat{r}(0)]$.

PROPOSITION 1: For sufficiently competitive markets (i.e., $\varepsilon>\bar{\varepsilon}$ ), the only symmetric equilibrium has banks choosing to hold no capital, pay $r_{\mathrm{G}}(0)$ to depositors, and invest in the gambling asset.

\section{Prudential Regulation}

Once markets are sufficiently competitive that gambling must occur in the free-market competitive equilibrium, some form of prudential regulation is necessary. A consensus has emerged among both economists and policy 
makers that a minimum capital requirement combined with effective monitoring of banks by a central regulator forms an effective basis for prudential regulation of banks. The underlying logic of capital requirements is that when the bank invests its own capital that capital acts as a bond, so that the bank bears some of the downside risk from investing in risky assets. (We call this the capital-at-risk effect.) Provided that the bank has sufficient capital at risk, the bank will choose to invest in the prudent asset in equilibrium.

An alternative form of prudential regulation is deposit-rate controls, creating a ceiling on the interest rate that banks may pay to depositors. By limiting the degree of competition in the deposit market, a deposit-rate control will increase the per-period profits captured by each bank, thereby increasing the franchise value. As described in Section II, once the franchise value at risk exceeds the one-period expected gain from gambling, the bank will choose to invest in the prudent asset.

To implement an effective policy of capital requirements (i.e., one that eliminates gambling as a competitive equilibrium), it must be the case that no profitable deviation to gambling is available to any bank. If banks are required to hold $k$ of capital, then the equilibrium interest rate, assuming that all banks invest in the prudent asset, will be $r_{\mathrm{P}}(k)$. If a bank were considering a deviation, then it would choose its deposit rate to maximize its return, conditional on all other banks paying $r_{\mathrm{P}}(k)$ and the bank investing in the gambling asset. For this deviation not to be profitable, and thus ensuring that a capital requirement of $k$ will implement a no-gambling equilibrium, it must be the case that $\operatorname{Max}_{r}\left\{V_{\mathrm{G}}\left(r, r_{\mathrm{P}}, k\right)\right\} \leq V_{\mathrm{P}}\left(r_{\mathrm{P}}, r_{\mathrm{P}}, k\right) .^{21}$ Define $\bar{k}$ as the minimum level of capital that satisfies the constraint. We know that $\bar{k}$ exists because, for sufficiently large $k$, the bank bears enough of the cost of gambling that its returns are strictly greater when it invests in the prudent asset. We can determine the comparative statics

\footnotetext{
${ }^{21}$ For notational simplicity, when writing $r_{\mathrm{P}}(k), r_{\mathrm{G}}(k)$, and $\hat{r}(k)$ as arguments of a function, we will suppress the fact that each of these depends on the level of capital deployed by the bank and write $r_{\mathrm{P}}, r_{\mathrm{G}}$, and $\hat{r}$ [i.e., $V_{\mathrm{P}}\left(r_{\mathrm{P}}, r_{\mathrm{P}}\right.$, $\left.\bar{k})=V_{\mathrm{P}}\left(r_{\mathrm{P}}(\bar{k}), r_{\mathrm{P}}(\bar{k}), \bar{k}\right)\right]$.
}

for the minimum effective capital requirement as well:

$$
\begin{gathered}
\partial \bar{k} / \partial \alpha<0 \\
\partial \bar{k} / \partial \gamma>0 \\
\partial \bar{k} / \partial \theta>0 .
\end{gathered}
$$

Since financial liberalization grants greater freedom to banks in determining their lending portfolio, we would expect that either $\gamma$ or $\theta$ (or both) would increase. This raises the possibility that the minimum effective capital requirement may increase as liberalization is introduced. ${ }^{22}$

Implementing an effective policy of depositrate controls is relatively straightforward. Since for all $r \leq \hat{r}(k)$ it is optimal for the bank to invest in the prudent asset, then any deposit-rate control of $\hat{r}(k)$ in combination with a minimum capital requirement of $k$ will implement a nogambling equilibrium. ${ }^{23}$ Furthermore, even if no capital requirements are used, a deposit-rate ceiling of $\hat{r}(0)$ will suffice. This leads naturally to Proposition 2.

PROPOSITION 2: Any Pareto-efficient outcome can be implemented by a combination of a minimum capital requirement of $k^{*}$ with $a$ deposit-rate control of $\hat{r}\left(k^{*}\right)$.

The income for the banks, depositors, and the government (as the deposit insurer) are determined as a function of the deposit rate, the level of capital held by banks, and whether the banks gamble or invest prudently. The Pareto frontier is defined by the set of outcomes such that no agent (bank, depositor, or the government) can

\footnotetext{
${ }^{22}$ This is potentially an important observation. One of the objectives of the Basle Accord was to create a "level playing field" for international competition. Yet if banks in different countries face different gambling opportunities and different degrees of competition, the optimal capital requirement will not be the same across countries.

${ }^{23}$ Normally, we think of deposit-rate controls as depositrate ceilings. If $k^{*}>\underline{k}$, where $\underline{k} \equiv\left\{r_{\mathrm{P}}(k)=\hat{r}(k)\right\}$, then in a competitive equilibrium with a deposit-rate ceiling but no floor, banks would offer an interest rate that is less than $\hat{r}\left(k^{*}\right)$. To implement the constrained social optimum, the regulator also would need to impose a deposit-rate floor of $\hat{r}\left(k^{*}\right)$ along with a capital requirement of $k^{*}$.
} 


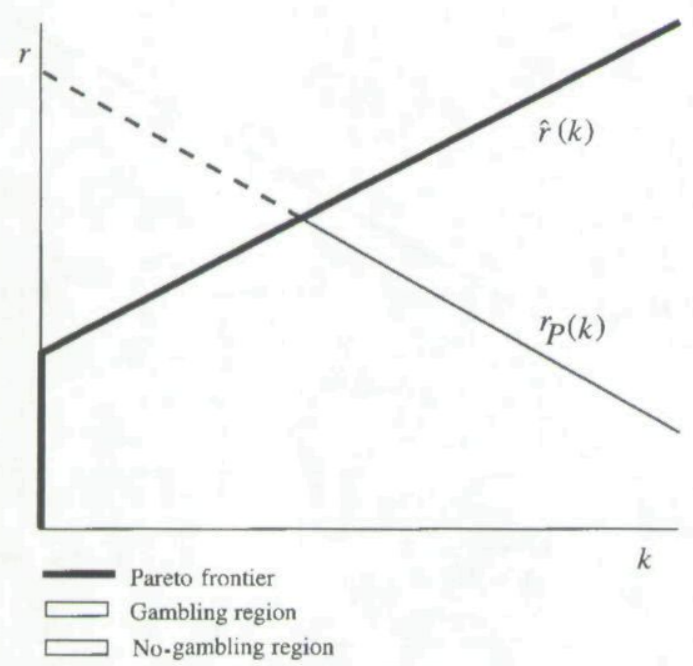

Figure 1. No-GAMBLING Region AND COMPETITIVE EQUILIBRIA

Notes: The line designated $\hat{r}(k)$ is the no-gambling condition, and the line designated $r_{\mathrm{P}}(k)$ is the equilibrium deposit rate conditional on prudent investment; $r_{\mathrm{p}}(k)$ above $\hat{r}(k)$ cannot be implemented, because banks strictly prefer gambling to prudent investment in this region.

be made better off without some other becoming worse off. Within the no-gambling region, the first part of the Pareto frontier is defined by the vertical axis under $\hat{r}(0)$ [i.e., all $r \leq \hat{r}(0)$ ]. (See Figure 1, where the no-gambling condition is upward sloping [i.e., when $\partial \hat{r} / \partial k>0$ ].)

When examining the no-gambling condition, we find, however, that it is not necessarily upward sloping:

$$
\begin{aligned}
\partial \hat{r} / \partial k= & (1-\delta)(\alpha-\theta \gamma) /(1-\theta) \\
& -\delta(\rho-\alpha)
\end{aligned}
$$

which implies that $\partial \hat{r} / \partial k \leq 0$ for $\delta \geq \bar{\delta} \equiv(\alpha-$ $\theta \gamma) /[\alpha-\theta \gamma+(1-\theta)(\rho-\alpha)]$. This finding implies that, for farsighted banks, increasing the amount of capital held by the bank actually increases the bank's incentives to gamble. This runs counter to the intuition traditionally found in the literature (see Bhattacharya, 1982). The traditional analysis has focused on the static role of bank capital. The greater the amount of the bank's own equity at risk, the greater is the extent to which the bank internalizes the cost of gambling. This static analysis has failed to include the dynamic effect of capital requirements on a bank's franchise value. Since holding capital is costly, the per-period future profits of the bank are lower, ceteris paribus, when bank capital increases. Thus, increasing the amount of capital held by the bank has two effects: the positive capital-at-risk effect and the negative franchise-value effect. This discussion is summarized in the following proposition.

PROPOSITION 3: When banks are sufficiently farsighted $(\bar{\delta} \leq \delta<1)$, the negative franchise-value effect dominates the positive capital-at-risk effect of capital requirements. Consequently, there always exists a policy of deposit-rate controls that Pareto-dominates any policy of capital requirements.

The Pareto-dominance result follows naturally from the condition that banks are farsighted because the no-gambling constraint is downward sloping. For any positive capital requirement, then, the interest rate realized is less than that obtained by simply using a deposit-rate control without a capital requirement [i.e., $\hat{r}(k) \leq \hat{r}(0)$ ]. A deposit-rate control of $\hat{r}(k)$, combined with no capital requirement, would yield the same returns to depositors and higher profits to banks, which would save banks the incremental capital costs $([\rho-\alpha] k)$. Whenever banks are sufficiently farsighted that the franchise-value effect dominates the capital-at-risk effect, then any policy of capital requirements is a Paretoinferior policy. Under these circumstances, the optimal capital requirement is always zero. For the remainder of the paper, we will assume that banks are sufficiently myopic that the no-gambling condition is upward sloping (i.e., $\partial \hat{r} / \partial k>0$ ), where it is possible that the optimal capital requirement can be positive. All of our results will also hold for the case when the no-gambling condition is downward sloping.

We have shown that we can always implement the constrained optimum using both capital requirements and deposit-rate controls. We now consider whether there are circumstances under which we can implement the optimum using just capital requirements and no deposit-rate 
controls - the set of policies usually associated with financial liberalization.

With no deposit-rate controls, banks can freely choose their deposit rates. To understand the effectiveness of using just a capital requirement, it is important to understand a bank's incentives to deviate by offering a different interest rate and switching its loan portfolio to the gambling asset. Define $\underline{k}$ by $r_{\mathrm{P}}(\underline{k})=\hat{r}(\underline{k})$. Lemma 1 , which is proved in the Appendix, derives from the fact that, at $\underline{k}$, the bank has an incentive to deviate by offering a higher interest rate and switching to the gambling asset.

LEMMA 1: The minimum effective capital requirement is strictly greater than $\underline{k}$ (i.e., $\bar{k}>\underline{k}$ ).

The intuition for Lemma 1 comes from the difference between how the no-gambling condition is determined in comparison to how the equilibrium interest rate is determined. The no-gambling condition is determined such that the bank has no incentive to gamble at the asset-allocation stage. The bank thus considers its return from gambling and prudent investing, conditional on having a fixed pool of deposits to invest. For the bank to be indifferent between investing in the prudent versus the gambling asset (which is the definition of $\hat{r})$, then the bank's current-period expected margin must be strictly greater from the gambling asset; that is,

$$
m_{\mathrm{G}}=m_{\mathrm{P}}(1-\delta \theta) /(1-\delta)>m_{\mathrm{P}} .
$$

When we consider the deposit-mobilization stage, the bank therefore has a greater incentive to mobilize deposits when it is gambling than when it invests prudently, because it earns a higher expected margin on its incremental deposits.

For any capital requirement greater than $\underline{k}$, the equilibrium interest rate is strictly inside the efficient frontier because $r_{\mathrm{P}}(k)$ is downward sloping. This implies that there exists some lower level of capital, $k_{0}$, such that $\hat{r}\left(k_{0}\right)=$ $r_{\mathrm{P}}(\bar{k})$ (see Figure 2). Thus, as an alternative to a capital requirement of $\bar{k}$, we could use a deposit-rate control of $\hat{r}\left(k_{0}\right)$ combined with a capital requirement of $k_{0}$. This alternative pol-

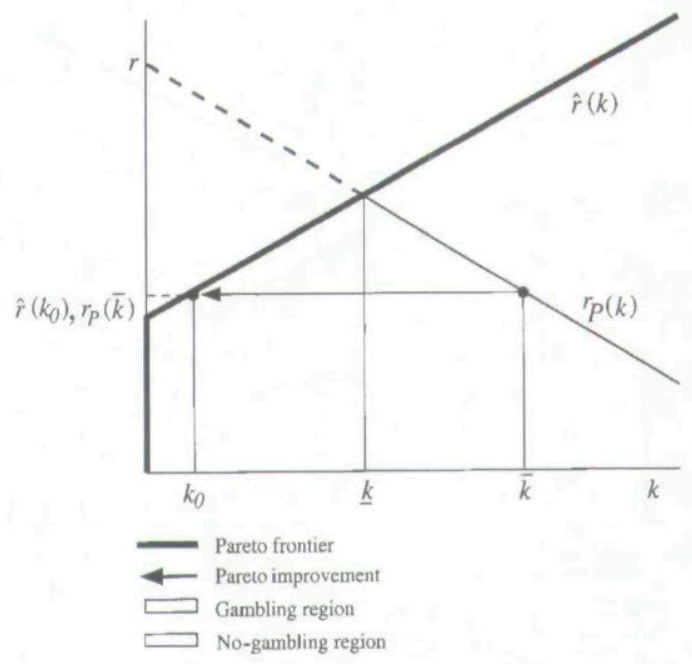

Figure 2. Pareto ImProvements WITH DEPOSIT-RATE CONTROLS

Notes: The line designated $\hat{r}(k)$ is the no-gambling condition, and the line designated $r_{\mathrm{p}}(k)$ is the equilibrium deposit rate conditional on prudent investment and no deposit-rate ceiling. A deposit-rate ceiling or $\bar{r}=r_{\mathrm{P}}(\bar{k})$ yields the same return and allows the government to reduce the capital requirement from $\bar{k}$ to $k_{\mathrm{o}}$ while still inducing prudent investment by the banks.

icy would yield an identical return to depositors while increasing the profits of the banks. Proposition 4 summarizes this result.

PROPOSITION 4: There always exists a policy regime consisting of both a capital requirement and a deposit-rate control that Paretodominates any policy regime that only uses a capital requirement.

This is a strong result. It states that the current policy regime practiced in most countries around the world (i.e., using just a capital requirement with no deposit-rate control) is a Pareto-inferior policy choice.

As long as a positive capital requirement is necessary to induce the prudent outcome, the capital-requirement-only regime is Pareto inefficient. This is particularly important for analyzing an alternative proposal for creating franchise value: the use of entry restrictions. Lowering the number of banks competing with each other has a qualitatively similar effect to 
reducing the interbank elasticity of deposits. ${ }^{24}$ This, in turn, will increase the equilibrium franchise value of the bank. It does not, however, allow the implementation of a Pareto-efficient outcome. As long as banks can freely determine deposit rates, each bank has a positive incentive to raise deposit rates along the Pareto frontier. Since entry restrictions do not affect the bank's deposit-rate-setting ability, this incentive problem precludes implementation of Paretoefficient outcomes.

A related issue is that we have so far assumed that the number of banks in the economy is exogenously fixed. Clearly, with endogenous entry, there exists the potential for the franchise value to be eroded by competition from new banks. Banks will only enter, however, when their sunk costs of entry are less than or equal to the ex post franchise value in the post-entry equilibrium. If these sunk costs exceed the necessary franchise value to support prudent investment, endogenous entry has no effect on our results. If the sunk costs are too low, our results can still be supported provided that the government charges a license fee such that the total sunk costs (entry costs plus license fee) equal the franchise value.

Finally, it is also interesting to consider the case where no capital requirements are used and regulators rely solely on deposit-rate controls. It is immediate that deposit-rate controls can only implement outcomes with $k=0$ and $r \leq \hat{r}(0)$. All these outcomes are Pareto efficient, but they implement only a subset of the Pareto frontier.

\section{Binding and Nonbinding Deposit-Rate Ceilings}

The results of the previous section develop the advantages of using deposit-rate ceilings as a mechanism of prudential regulation. The experience of the United States in the 1960's and 1970's suggests that there are potential difficulties caused by the use of deposit-rate ceilings that were not formally analyzed in our stylized model. In particular, when banks are precluded from freely determining deposit rates, they may seek to capture deposits through other forms of non-price compe-

\footnotetext{
${ }^{24}$ This can be derived explicitly in a Hotelling model.
}

tition, like giving away consumer goods ("toasters"), opening new branches, and advertising. This non-price competition is inefficient if it compensates consumers with an inferior substitute, and it can have the adverse consequence of dissipating part of the franchise value induced by the depositrate ceiling. ${ }^{25}$

It is not unambiguous, however, that non-price competition is socially wasteful. In particular, when the financial sector is underdeveloped, nonprice competition can have the positive effect of deepening the financial sector. In Hellmann et al. (1996), we consider an economy where there are underserved deposit markets. Banks need to make some investments (such as building a branch network) to attract customers. In these circumstances non-price competition is socially desirable, but private banks only have the incentive to make these investments if there are binding deposit-rate controls. In these circumstances the gains from financial deepening may exceed the inefficiencies induced by non-price competition. ${ }^{26}$

Of course, those results only apply in a developing-country context. In an advanced industrial economy, where almost all households have access to the financial sector, there are few potential gains from further investments in expanding the number of branches. In this context, a deposit-rate ceiling is likely to induce some socially wasteful non-price competition, like what the United States experienced in the 1960 's and 1970's. Moreover, the proliferation of financial products available to households (stock, bond, and money-market mutual funds, etc.) implies that households are more likely to

\footnotetext{
${ }^{25}$ Non-price competition, however, will not fully dissipate the rents induced by a deposit-rate ceiling. Banks will use instruments of non-price competition until the marginal cost of attracting another unit of deposit equals the marginal return. With increasing marginal costs, then, the bank will capture rents on all of its inframarginal deposits.

${ }^{26}$ Similarly, non-price competition may have value when entry is endogenous. As discussed in the previous section, new banks will enter the market as long as the sunk costs of entry are less than the ex post franchise value achieved in the post-entry game. If the sunk costs of entry increase when the banks engage in more non-price competition (i.e., building branches with heavy marble content), then the equilibrium level of franchise value that can be supported likewise increases. Thus non-price competition can even have a positive effect of enhancing banks' commitment to invest in the prudent asset.
} 
substitute out of deposits in response to a binding ceiling.

A related concern arises about the information requirements implied by a policy of using deposit-rate ceilings as a tool of prudential regulation. In this policy regime, it is the government that determines the rate of return on deposits. But a government regulator may have difficulty implementing the optimal deposit-rate ceiling, particularly in response to significant macroeconomic shocks. Clearly, this was the case experienced by the United States in the 1970's. Regulation Q set a nominal ceiling on rates. Following the oil shock in 1973, that ceiling was below the rate of inflation, forcing banks to offer depositors a negative real rate of return and encouraging depositors to switch to other financial assets.

Even under circumstances where a binding deposit-rate ceiling is not the appropriate policy, we do believe that deposit-rate ceilings can be an effective tool of prudential regulation. This is because deposit-rate ceilings may be useful even if they are not binding in equilibrium. Nonbinding deposit-rate ceilings do not affect banks that invest their assets prudently but may constrain banks that want to pursue a risky gambling strategy. ${ }^{27}$ Nonbinding depositrate ceilings then have the attractive feature that they do not invite inefficient non-price competition. They also reduce the information problems of the regulator in the sense that they allow for a greater margin of error.

To see this in our model, note that gambling banks always want to offer a higher deposit rate than prudent banks. When the other banks are investing prudently, a bank that deviates to gambling will choose its deposit rate according to $r_{\mathrm{D}}(k) \equiv \arg \max _{r}\left\{V_{\mathrm{G}}\left(r, r_{\mathrm{P}}, k\right)\right\}$. Whenever gambling is potentially attractive, the bank earns a higher margin on the gambling investment than on prudent investment [i.e., $m_{\mathrm{G}}(k)>$ $m_{\mathrm{p}}(k)$ ], so the deviation occurs by offering a higher deposit rate [i.e., $r_{\mathrm{D}}(k)>r_{\mathrm{P}}(k)$ ]. Thus, should the government set a deposit-rate ceiling

\footnotetext{
${ }^{27}$ We use the term "nonbinding" to refer to the effect of the deposit-rate ceiling on the equilibrium deposit rate. The deposit-rate ceiling does bind, however, on any bank considering a deviation to gambling. That is from whence it derives it force.
}

$\bar{r}$ such that $r_{\mathrm{P}}(k)<\bar{r}<r_{\mathrm{D}}(k)$, then the policy will have no effect on the equilibrium deposit rate, while at the same time reducing the returns to gambling [because $V_{\mathrm{G}}\left(\bar{r}, r_{\mathrm{P}}, k\right)<V_{\mathrm{G}}\left(r_{\mathrm{D}}\right.$, $\left.\left.r_{\mathrm{p}}, k\right)\right]$.

This is important, because (from Lemma 1), it is the gambling bank's excess incentive to raise deposit rates that, in the absence of a deposit-rate ceiling, forces the government to set a capital requirement of $\bar{k}>\underline{k}$. If the government uses a deposit-rate ceiling $\bar{r}$ such that $r_{\mathrm{P}}(k)<\bar{r} \leq \hat{r}(k)$ for any $\underline{k}<k \leq \bar{k}$, then all banks are constrained to offer deposit rates that satisfy the no-gambling condition, and a deviation to gambling will not be profitable. ${ }^{28}$ This leads to Proposition 5.

PROPOSITION 5: For $\underline{k}<k \leq \bar{k}$, if the government uses a nonbinding deposit-rate ceiling $\bar{r} \in\left(r_{\mathrm{P}}(k), \hat{r}(k)\right]$ and a binding capital requirement of $k$, the equilibrium deposit rate will be determined by market competition $\left[r_{\mathrm{P}}(k)\right]$, and all banks will invest prudently.

From Propositions 1 and 4, we know that, in the absence of a deposit-rate ceiling, the government needs to impose a binding capital requirement and that constraint results in the selection of a Pareto-inferior outcome. The strongest argument for selecting this outcome is that, when the government just uses capital requirements, the deposit rate is determined by market forces, and (as discussed above) that has value for reasons not captured by our stylized model. Proposition 5 responds directly to this argument. With a deposit-rate ceiling that does not bind in equilibrium, deposit rates will still be determined by market forces, but we can relax the constraint that binds on bank capital. This will then implement an outcome closer to the Pareto frontier than can be implemented using just capital requirements.

Of course, the government still is required to set an appropriate deposit-rate ceiling. Set too low, it will bind, with all the implications discussed above, but set too high, it will not pre-

\footnotetext{
${ }^{28}$ Note that, for all $k<k \leq \bar{k}, r_{\mathrm{P}}(k)<\hat{r}(k)<r_{\mathrm{D}}(k)$, so the ceiling does not bind in equilibrium.
} 
clude banks from gambling. ${ }^{29}$ One thing that is clear from the United States's experience with Regulation Q is that any deposit-rate ceiling should be set in real and not nominal terms, so that the policy is not undermined by a large change in inflation expectations. We suggest that a reasonable benchmark is the rate of return on equivalent-duration Treasury bills. The yields on government notes are determined by the market, and they automatically incorporate inflation expectations. If the deposit-rate ceiling were set at some fixed premium above the equivalent-duration Treasury yield, then the ceiling would adjust in a timely way to changes in market conditions. ${ }^{30}$

There is an additional reason why it makes sense to limit the premium over Treasury rates that banks may offer depositors: bank deposits are government insured, and so banks are essentially borrowing using the government's credit rating. Shoven et al. (1992) link the sharp and sudden increase in the real interest rates in the 1980's to the impact of insolvent S\&Ls offering high rates on certificates of deposits in competition with Treasury securities. Essentially, when insured financial institutions deviate to gambling, they can use the government's own credit rating to offer high deposit rates in competition with the government.

\section{Endogenous Rates of Return}

So far we have taken the cost of capital $\rho$ and the return to the lending portfolio $\alpha$ as given. In general, however, one may expect that, while any individual bank may take these as given, they are endogenously determined at an aggregate level. This may give rise to feedback from the policy interventions to the now endogenous return variables. In this section we introduce a simple extension of the model that allows us to

\footnotetext{
${ }^{29}$ Finding the appropriate range of deposit-rate ceilings may be further complicated by bank heterogeneity. Obviously, the same problems apply to capital requirements.

${ }^{30}$ Certificates of deposit may offer higher yields than equivalent Treasury securities. Much of this premium can be explained by differences in the tax treatment of the two assets: interest income from CDs are subject to state tax, whereas Treasury-bill income is exempt (see John B. Shoven et al., 1992).
}

analyze the cost of bank capital and the return to bank lending endogenously. The first main insight is that the assumption that bank capital is costly (i.e., $\rho>\alpha$ ) is actually a natural consequence of the fact that a binding capital requirement inflates the bank's demand for scarce equity capital. The second insight is that the feedback effect from an endogenous determination of these rates of return tends to exacerbate the negative impact that capital requirements can have on the incentive to invest prudently.

It is a well-known fact that multiple feedback effects may occur at a general-equilibrium level. The approach we will take here is to limit ourselves to a few first-order effects that can be expected of many reasonable equilibrium models. In particular, below we will introduce some aggregate demand and supply functions that exhibit a limited number of intuitive properties. A detailed microeconomic specification of the technology and preferences that would lead to these supply and demand functions is beyond the scope of this paper. Instead, we take a "reduced-form" approach that allows us to capture fairly broad equilibrium feedback effects that do not depend on any specific underlying model.

To model the endogeneity of $\rho$ and $\alpha$, we will use a demand and supply model for bank equity and bank lending, respectively. Consider first the market for bank equity. Suppose that savers can either put their savings into deposits or supply funds to a market for bank equity. With a slight abuse of notation, denote the aggregate supply of deposits by $D$ and the aggregate supply of funds for bank equity by $E{ }^{31}$ A reasonable assumption that would be predicted by many general-equilibrium models is that the supply of funds is (weakly) increasing in their own returns and (weakly) decreasing in the returns of substitutes. Moreover, it seems reasonable that the own-price effect dominates the cross-price effect. We therefore assume that $D(r, \rho)$ and $E(r, \rho)$ satisfy $D_{r}(\equiv \partial D / \partial r) \geq 0$, $D_{\rho} \leq 0, D_{r}+D_{\rho} \geq 0, E_{\rho} \geq 0, E_{r} \leq 0$, and $E_{\rho}+E_{r} \geq 0$.

\footnotetext{
${ }^{31}$ The aggregate functions are simply obtained by multiplying the individual supply functions by the number of banks, $N$.
} 
The implicit idea behind these supply functions is that bank equity and deposits have different characteristics that savers might care about. First, bank deposits provide liquidity on demand and other related services such as check-writing. Second there may be transaction costs for investing funds in bank equity, and investors may need to be more sophisticated to participate in this market. Finally, there may be different levels of risk associated with these securities. While analytical tractability prevents us from modeling these effects directly, our reduced-form demand functions are consistent with these interpretations.

The bank's demand for equity depends on capital requirements as well as on the relationship between $\rho$ and $\alpha$. It is convenient to express the demand as a fraction $\tilde{k}$ of deposits. Let $k$ be the required minimum level of capital. Then the bank's demand for capital is given by $\tilde{k} D$, where $\tilde{k}=\infty$ if $\rho<\alpha, \tilde{k} \in[k, \infty)$ if $\rho=$ $\alpha$, and $\tilde{k}=k$ if $\rho>\alpha$. This simply says that banks would be willing to raise any amount of equity capital if $\rho<\alpha$ but only want to raise the minimum required when $\rho<\alpha$. At $\rho=\alpha$, they are indifferent as to the amount of capital raised.

Bank equity is demanded and supplied in a standard competitive market where individual banks and savers take the price of equity capital $\rho$ as given. The equilibrium is determined by the interaction of supply and demand. Clearly $\rho<$ $\alpha$ cannot be an equilibrium, since any individual bank would offer a higher return to equityproviders to attract additional capital. To see whether $\rho=\alpha$ or $\rho>\alpha$, define $k^{\mathrm{v}} \geq 0$ such that $E(\alpha, r)=k^{\mathrm{v}} D(r, \alpha) \cdot k^{\mathrm{v}}(r)$ is the amount of capital that banks are willing to hold voluntarily (hence the superscript v) even in the absence of capital requirements. ${ }^{32}$ We now distinguish the case where this voluntary level of capital is sufficiently large to support a prudent equilibrium. Suppose first that there is an abundant supply of funds for bank equity. In particular, consider the case where $k^{\mathrm{v}}\left(r_{\mathrm{P}}(\bar{k})\right) \geq \bar{k}$. In this case, banks voluntarily maintain sufficiently large amounts of capital not to gamble. Such an economy would have no problem of moral haz-

\footnotetext{
${ }^{32}$ It is straightforward to check that $k^{\mathrm{v}}$ is decreasing in $r$. This is also true when $\alpha$ is endogenous.
}

ard in banking, and no prudential regulation would be necessary.

Unfortunately the real world does not seem to correspond to this scenario. We note that in general the return to bank equity needs to compensate for the lack of liquidity and other inconveniences. This suggests that the supply of funds for bank equity capital may be somewhat scarce. In particular, when $k^{\mathrm{v}}\left(r_{\mathrm{P}}(\bar{k})\right)<\bar{k}$, the amount of capital that bank are willing to hold voluntarily is not enough to induce prudent behavior. Suppose first that there are no capital requirements. If $\rho>\alpha$, then banks would not be willing to hold any capital. It follows that $\rho=\alpha$ in equilibrium, and banks hold less capital than necessary to prevent gambling. While the equity market is clearing and the return to bank assets equals their cost of capital, gambling occurs in equilibrium.

It is precisely under these circumstances that a regulator would want to impose some capital requirements. But imposing a binding capital requirement will drive up demand and thus the price of equity. For the minimum effective capital requirement $\bar{k}$, the equity market clears at some $\rho>\alpha$, such that $E(\rho, r)=\bar{k} D(r, \rho)$. We have thus shown that the high cost of capital is endogenously induced by regulation (i.e., it is the natural consequence of a binding capital requirement).

Taking total derivatives in $E(\rho, r)=k D(r$, $\rho)$, we immediately obtain (in obvious notation) $\rho_{k}=D /\left(k E_{\rho}-D_{\rho}\right) \geq 0$ and $\rho_{r}=\left(k D_{r}-\right.$ $\left.E_{r}\right) /\left(E_{\rho}-k D_{\rho}\right) \geq 0$. If the cost of capital is endogenous, it is an increasing function of both $k$ and $r$. Higher capital requirements inflate the banks' demand for capital, thus requiring a higher rate of return. Higher deposit rates also inflate the banks' demand for capital, to match the increased amount of deposits. In addition, higher deposit rates make it harder to convince savers to invest in bank equity and thus also require increased returns to lure savers back into the bank equity market.

We also extend the model to allow for an endogenous determination of the return to lending, $\alpha$. Again, a fully specified general-equilibrium model is beyond the scope of this paper, but we can use a reduced-form approach to capture the main dependency of price on quantity (i.e., the dependency of the return to lending on the total 
volume of bank lending). ${ }^{33}$ Denote the demand for bank loans by $L(\alpha)$. Most models of bank lending would predict that loan demand is a (weakly) decreasing function of $\alpha$ (i.e., as banks increase their lending rates and/or tighten other terms [an increase in $\alpha$ ], firms are likely to curtail their demand for loans). The supply of loans is given by the total bank assets $A=D+E$. The equilibrium in the lending market is then given by $L(\alpha)=A(r, \rho(r, k))$, where $\rho(r, k)$ from above. Taking total derivatives and using $L_{\alpha}<0, A_{r}=$ $D_{r}+E_{r} \geq 0$, and $A_{\rho}=D_{\rho}+E_{\rho} \geq 0$, we obtain $\alpha_{r}=\left(A_{r}+A_{\rho} \rho_{r}\right) / L_{\alpha} \leq 0$ and $\alpha_{k}=A_{\rho} \rho_{k} / L_{\alpha} \leq 0$. Increases in the deposit rate or the capital requirement drive down the return to bank lending.

We are now in a position to examine how the endogeneity of $\rho$ and $\alpha$ affects the policy tradeoffs. For this we revisit the no-gambling condition, which defines the set of feasible combinations of $r$ and $k$ that a policy maker can implement. The proof of Proposition 6 is given in the Appendix.

PROPOSITION 6: Consider an increase in the capital requirement in the extended model. In addition to the usual capital-at-risk and franchise-value effects derived in Proposition 3, the endogeneity of the cost of capital $\rho$ and the return to bank lending $\alpha$ implies that there are additional "feedback" effects that further reduce the incentive to invest prudently.

The intuition for this result is as follows. We have seen that an increase in capital requirements increases the cost of capital. But that further reduces the franchise value, thus undermining the incentive to invest prudently. Moreover, the increase in capital requirements also reduces the return to bank lending, which has a negative effect both on the franchise value and the static capital-at-risk effect. ${ }^{34}$

Figure 3 illustrates the implication of this

\footnotetext{
${ }^{33}$ An interesting point to note is that repeated play in the lending market itself may lead to "franchise-value" effects See Serdar I. Dinç (1997) for a model along those lines.

${ }^{34}$ Note that we assumed here that the return to gambling, as characterized by $\theta, \beta$, and $\gamma$, remains constant. This seems the most natural assumption, given that in equilibrium no gambling investments are ever made. It is also straightforward to relax this assumption.
}

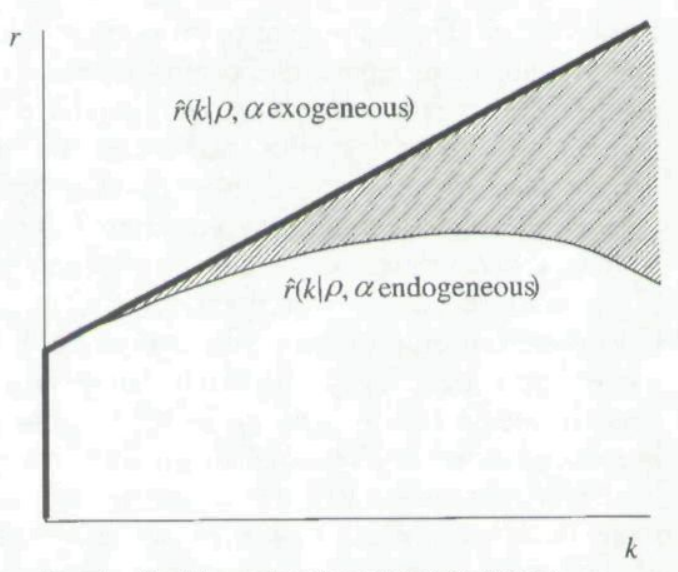

Gambling region when returns are exogenous

Additional gambling region when returns are endogenous No-gambling region

Figure 3. THE EFFects of Endogenous RATES OF RETURN

proposition. If $\rho$ and $\alpha$ are exogenous, $\hat{r}(k)$ is a straight line. If, however, $\rho$ and $\alpha$ are endogenous, the slope of $\hat{r}(k)$ is always lower, so that the endogenous $\hat{r}(k)$ locus lies below the exogenous $\hat{r}(k)$ line. ${ }^{35}$ This implies that the regulator now faces a smaller set of $r$ and $k$ that can be used to implement prudent banking equilibria. We also noted before that if the franchise-value effect dominates, $\hat{r}(k)$ would have a negative slope. When $\rho$ and $\alpha$ are endogenous, this is even more likely, in the sense that the feedback effects provide an additional downward force on the $\hat{r}(k)$ locus. This means that, if the feedback effects are sufficiently strong, then an increase in capital requirements can never induce more prudent banking behavior.

It is worth reexamining our results from Section II in the context of endogenous rates of return. In general, our claims about the potential costs of capital requirements and the potential benefits of deposit-rate controls in combating moral hazard are strengthened, but our claims about Pareto efficiency must be relaxed. Propositions 1 and 2 follow immediately in the present context, and Proposition 6 is the generalized version of

\footnotetext{
${ }^{35}$ The exogenous $\hat{r}(k)$ line is drawn for the value of $\rho$ and $\alpha$ at $\hat{r}(0)$.
} 
Proposition 3. The main point of Proposition 5 is that a nonbinding deposit-rate control allows the government to reduce the minimum capital requirement while still having market-determined deposit rates. With endogenous rates of return, relaxing the capital-requirement constraint has an additional benefit because the cost of bank equity $\rho$ will also decline. We must relax our claims, however, from Proposition 4 because we can no longer apply a formal Pareto analysis in this extended model. This is not surprising: we have introduced some additional constituencies into the model, and the more distinct agents there are, the more likely any policy will adversely affect at least one type of agent. ${ }^{36}$ For instance, a reduction of capital requirements, as in Figure 2, can have a negative impact on bank lending, so that borrowers may be worse off. Obviously the reduction also creates cost savings for the banks (since, in equilibrium, $\rho>\alpha) .{ }^{37}$ In order to assess the full impact of any policy intervention, one may thus have to consider more complex welfare trade-offs among all the constituencies. ${ }^{38}$ Our basic result, however, that deposit-rate controls give the regulators an additional instrument that may be used to complement capital requirements, is robust in this extended model.

\footnotetext{
${ }^{36}$ Technically, another reason why the Pareto criterion cannot be applied in this extended model is that the reducedform supply and demand functions were specified without specific references to utility functions.

${ }^{37}$ It is possible that another policy may yield a Pareto improvement for at least the set of depositors, bank owners, and bank borrowers. Consider a policy $(r, k)$ with $r>r_{\mathrm{P}}(\bar{k})$ and $k<\bar{k}$ such that bank franchise value is the same under both policies [i.e., $V_{\mathrm{P}}(r, k)=V_{\mathrm{P}}\left(r_{\mathrm{P}}, \bar{k}\right)$ ]. Clearly, banks are indifferent, and depositors are better off. If the total banking assets are greater under the alternative policy [i.e., $D(r$, $\left.r)(1+k)>D\left(r_{\mathrm{P}}, r_{\mathrm{P}}\right)(1+\bar{k})\right]$, then bank borrowers are better off as well. While this condition is not satisfied in general (e.g., when deposit savings are inelastic), it will hold provided that the total elasticity of savings is sufficiently large or the supply of funds for bank equity is sufficiently inelastic.

${ }^{38}$ Another constituency that we have not considered so far is the insurer of deposits. In the model, banks are homogenous, and so the regulator may find a policy such that in equilibrium no gambling occurs at all. With heterogeneity and noise in the economy, some banks may fail. Capital requirements may have another useful role in protecting the insurer of deposits.
}

\section{Conclusion}

The aim of this paper has been to understand the interaction between financial liberalization and prudential regulation. Financial liberalization tends to increase the intensity of competition between banks at the same time that banks are given greater freedom to allocate assets and to determine interest rates. As a consequence, the potential scope for gambling by banks also increases. We consider two potential instruments of prudential regulation: capital requirements and deposit-rate controls. We first point out that, in a dynamic economy, capital requirements may not always be as powerful as previously thought. This is because, in addition to a one-period capital-at-risk effect that reduces the incentive to gamble, there is a future-franchisevalue effect that increases the incentive to gamble. We then show that, while a sufficiently large capital requirement can generate an equilibrium in which banks choose to invest efficiently, the equilibrium is Pareto inefficient. In particular, one can always find a regulatory regime that uses both deposit-rate controls and capital requirements that Pareto-dominates any regulatory regime that uses just capital requirements.

Three key intuitions are developed through our analysis of this model: freely determined deposit rates undermine the franchise value of banks; capital requirements are costly because they force banks to hold expensive capital; and the use of either binding or nonbinding depositrate ceilings to complement capital requirements creates additional policy flexibility that allows the government to relax a binding constraint on capital, reducing the total costs imposed by the capital requirement.

While our analysis has focused on the use of deposit-rate controls as an additional tool of prudential regulation to prevent moral hazard, it is worth recognizing that there are other policy instruments that could improve on capital requirements. For example, regulations such as asset-class restrictions and exposure rules may help combat the moral-hazard problem, particularly if they limit banks' ability to invest in assets that facilitate gambling. Risk-based deposit-insurance premiums could also lessen the incentives of banks to gamble, although effec- 
tively implementing such a policy and appropriately defining risk classes presents a challenge for regulators.

Another policy recommendation that could address the moral-hazard problem is the use of "speed limits" on growth. As shown in our analysis, gambling strategies are based on rapid growth by banks to take advantage of the artificially high current return on the gambling asset. A policy that set limits on bank growth would lower the return from the gambling strategy, reducing bank incentives to make this deviation. This policy would have trade-offs, however, as banks with either better investment opportunities or lower costs of intermediation would be limited in their rate of growth as well.

\section{APPENDIX}

\section{PROOF OF LEMMA 1:}

First we show that for a sufficiently low capital requirement $\left(k<\tilde{k}\right.$, where $\tilde{k} \equiv\left\{m_{\mathrm{G}}\left(r_{\mathrm{P}}\right.\right.$, $\left.\left.k)=\theta m_{\mathrm{P}}\left(r_{\mathrm{P}}, k\right)\right\}\right), \arg \max _{r}\left\{V_{\mathrm{G}}\left(r, r_{\mathrm{P}}, k\right)\right\}>$ $r_{\mathrm{P}}(k)$, and also $\max _{r}\left\{V_{\mathrm{G}}\left(r, r_{\mathrm{P}}, k\right)\right\}>V_{\mathrm{G}}\left(r_{\mathrm{P}}\right.$, $\left.r_{\mathrm{P}}, k\right)$. For this we need to show that $\partial V_{\mathrm{G}} l$ $\left.\partial r_{i}\right|_{r_{i}=r_{\mathrm{P}}(k)}>0$ :

$$
\begin{aligned}
\partial V_{\mathrm{G}} / \partial r_{i}=\{ & m_{\mathrm{G}}\left(r_{\mathrm{P}}, k\right)\left[\partial D\left(r_{\mathrm{P}}, r_{\mathrm{P}}\right) / \partial r_{i}\right] \\
& \left.-\theta D\left(r_{\mathrm{P}}, r_{\mathrm{P}}\right)\right\} /(1-\delta \theta) .
\end{aligned}
$$

From the first-order condition that defines $r_{\mathrm{P}}(k)$, we have $D\left(r_{\mathrm{P}}, r_{\mathrm{P}}\right)=m_{\mathrm{P}}\left(r_{\mathrm{P}}, k\right)\left[\partial D\left(r_{\mathrm{P}}\right.\right.$, $\left.\left.r_{\mathrm{P}}\right) / \partial r_{i}\right]$, which implies that

$$
\begin{aligned}
\partial V_{\mathrm{G}} / \partial r_{i}=\{ & m_{\mathrm{G}}\left(r_{\mathrm{P}}, k\right)\left[\partial D\left(r_{\mathrm{P}}, r_{\mathrm{P}}\right) / \partial r_{i}\right] \\
& \left.-\theta m_{\mathrm{P}}\left(r_{\mathrm{P}}, k\right)\right\} /(1-\delta \theta)>0
\end{aligned}
$$

whenever $k \leq \tilde{k}$.

From the definition of $\bar{k}$, we have $\max _{r}\left\{V_{\mathrm{G}}\left(r, r_{\mathrm{P}}, \bar{k}\right)\right\}=V_{\mathrm{P}}\left(r_{\mathrm{P}}, r_{\mathrm{P}}, \bar{k}\right)$. From above, provided that $\bar{k}<\tilde{k}, \max _{r}\left\{V_{\mathrm{G}}\left(r, r_{\mathrm{P}}\right.\right.$, $\bar{k})\}>V_{\mathrm{G}}\left(r_{\mathrm{P}}, r_{\mathrm{P}}, \bar{k}\right)$, which implies that $V_{\mathrm{P}}\left(r_{\mathrm{P}}\right.$, $\left.\left.r_{\mathrm{P}}, \bar{k}\right)\right\}>V_{\mathrm{G}}\left(r_{\mathrm{P}}, r_{\mathrm{P}}, \bar{k}\right)$. From the definition of $\left.\hat{r}(k), V_{\mathrm{P}}(\hat{r}, \hat{r}, \bar{k})\right\}=V_{\mathrm{G}}(\hat{r}, \hat{r}, \bar{k})$. Thus, in the competitive equilibrium using just capital requirements, the bank must earn strictly greater profits from choosing the prudent asset versus gambling. The maximum deposit rate with no gambling, however, is defined when profits are equal regardless of asset choice. Because $\partial V_{\mathrm{p}} /$ $\partial r<0$, it must be the case that the bank pays a strictly lower deposit rate (i.e., $\left.r_{\mathrm{P}}(\bar{k})<\hat{r}(\bar{k})\right)$. For $\bar{k} \geq \tilde{k}$, we know that $m_{\mathrm{G}}\left(r_{\mathrm{P}}, \bar{k}\right) \leq \theta m_{\mathrm{P}}\left(r_{\mathrm{P}}\right.$, $\bar{k})$, whereas $m_{\mathrm{G}}(\hat{r}, \bar{k})=m_{\mathrm{P}}(\hat{r}, \bar{k})(1-\delta \theta) /$ $(1-\delta)$. Because the gambling profit margin falls less rapidly in $r$ than does the prudent profit margin (i.e., $0>\partial m_{\mathrm{G}} / \partial r>\partial m_{\mathrm{P}} / \partial r$ ), then $r_{\mathrm{P}}(\bar{k})<\hat{r}(\bar{k})$. Because $r_{\mathrm{P}}(\underline{k})=\hat{r}(\underline{k})$ and $\partial r_{\mathrm{P}} / \partial k<0$, we must have $\bar{k}>\underline{k}$.

\section{PROOF OF PROPOSITION 6:}

Consider the maximal deposit rate $\hat{r}$ consistent with the no-gambling equilibrium. Let

$$
\begin{aligned}
\hat{r}= & (1-\delta)(1+k)[\alpha(\hat{r}, k)-\theta \gamma] /(1-\theta) \\
& +\delta[\alpha(\hat{r}, k)(1+k)-\rho(\hat{r}, k) k] \\
\equiv & f(k, \alpha(\hat{r}, k), \rho(\hat{r}, k)) .
\end{aligned}
$$

This defines an implicit function for $\hat{r}(k)$. Totally differentiating, we obtain

\section{$d \hat{r} / d k$}

$$
=\left(f_{k}+f_{\alpha} \alpha_{k}+f_{\rho} \rho_{k}\right) /\left(1-f_{\alpha} \alpha_{r}-f_{\rho} \rho_{r}\right) .
$$

The sum of the capital-at-risk and franchisevalue effects (derived for Proposition 3) are given by $f_{k}=(1-\delta)(\alpha-\theta \gamma) /(1-\theta)-$ $\delta(\rho-\alpha)$. Using $f_{\alpha}=(1-\delta)(1+k) /(1-$ $\theta)>0$ and $f_{\rho}=-\delta k \leq 0$, we immediately obtain $d \hat{r} / d k \leq f_{k}$ when $\rho$ and $\alpha$ are endogenously determined.

\section{REFERENCES}

Akerlof, George A. and Romer, Paul M. "Looting: The Economic Underworld of Bankruptcy for Profit." Brookings Papers on Economic Activity, September 1993, (2), pp. $1-60$.

Besanko, David and Kanatas, George. "The Regulation of Bank Capital: Do Capital Standards Promote Bank Safety?" Journal of Financial Intermediation, April 1996, 5(4), pp. 160-83.

Bhattacharya, Sudipto. "Aspects of Monetary and Banking Theory and Moral Hazard." 
Journal of Finance, May 1982, 37(2), pp. 371-84.

Calomiris, Charles W. and Kahn, Charles M. "The Role of Demandable Debt in Structuring Optimal Banking Arrangements." American Economic Review, June 1991, 81(3), pp. 497-513.

Caprio, Gerard, Jr. and Klingebiel, Daniela. "Bank Insolvency: Bad Luck, Bad Policy, or Bad Banking?" in Michael Bruno and Boris Pleskovic, eds., Annual World Bank Conference on Development Economics, 1996. Washington, DC: World Bank, 1997, pp. 79104.

Caprio, Gerard, Jr. and Summers, Lawrence H. "Finance and Its Reform: Beyond LaissezFaire," in D. Papadimitriou, ed., Stability of the financial system. New York: MacMillan, 1996, pp. 400-21.

Chan, Yuk-Shee; Greenbaum, Stuart I. and Thakor, Anjan V. "Is Fairly Priced Deposit Insurance Possible?" Journal of Finance, March 1992, 47(1), pp. 227-45.

Cole, Rebel A.; McKenzie, Joseph A. and White, Lawrence J. "Deregulation Gone Awry: Moral Hazard in the Savings and Loan Industry," in A. Cottrell, M. Lawlor, and J. Woo, eds., The causes and consequences of depository institutions failures. Boston, MA: Kluwer, 1995, pp. 29-73.

Demirgüç-Kunt, Asli and Detragiache, Enrica. "The Determinants of Banking Crises: Evidence from Developed and Developing Countries." Mimeo, World Bank, 1997.

. "Financial Liberalization and Financial Fragility," in Boris Pleskovic and Joseph E. Stiglitz, eds., Annual World Bank Conference on Development Economics, 1997. Washington, DC: World Bank, 1998, pp. 303-31.

Demsetz, Rebecca S.; Saidenberg, Marc R. and Strahan, Philip E. "Banks with Something to Lose: The Disciplinary Role of Franchise Value." Economic Policy Review (Federal Reserve Bank of New York), October 1996, 2(2), pp. 1-14.

Dewatripont, Mathias and Tirole, Jean. The prudential regulation of banks. Cambridge, MA: MIT Press, 1994.

Diamond, Douglas W. "Reputation Acquisition in Debt Markets." Journal of Political Economy, August 1989, 97(4), pp. 828-62.
Dinç, Serdar I. "Bank Reputation, Bank Commitment, and the Effects of Competition in Credit Markets." Mimeo, Stanford University, 1997.

Fischer, Klaus P. and Chénard, Martin. "Financial Liberalization Causes Banking Systems Fragility." Centre de Recherche en Économie et Finance Appliqueés, Université Laval (Canada), Working Paper No. 97-12, June 1997.

Flannery, Mark J. "Debt Maturity and the Deadweight Cost of Leverage: Optimally Financing Banking Firms." American Economic Review, March 1994, 84(1), pp. 320-31.

Genotte, Gerard and Pyle, David. "Capital Controls and Bank Risk." Journal of Banking and Finance, September 1991, 15(5), pp. 805-24.

Gianmarino, Ronald M.; Lewis, Tracy R. and Sappington, David E. M. "An Incentive Approach to Banking Regulation." Journal of Finance, September 1993, 48(4), pp. 152342.

Gorton, Gary and Winton, Andrew. "Bank Capital Regulation in General Equilibrium." National Bureau of Economic Research (Cambridge, MA) Working Paper No. 5244, 1997.

Hellmann, Thomas F. and Murdock, Kevin C. "Financial Sector Development Policy: The Importance of Reputational Capital and Governance," in R. Sabot and I. Skékely, eds., Development strategy and management of the market economy, Vol. 2. Oxford: Clarendon, 1997, pp. 269-323.

Hellmann, Thomas F.; Murdock, Kevin C. and Stiglitz, Joseph E. "Deposit Mobilization Through Financial Restraint," in N. Hermes and R. Lensink, eds., Financial development and economic growth: Theory and experiences from developing economies. London: Routledge, 1996, pp. 219-46. . "Financial Restraint: Toward a New Paradigm," in M. Aoki, M. Okuno-Fujiwara, and $\mathrm{H}$. Kim, eds., The role of government in East Asian economic development: Comparative institutional analysis. Oxford: Clarendon, 1997, pp. 163-207.

. "Financial Restraint and the Market Enhancing View," in Y. Hayami and M. Aoki, eds., The institutional foundations of East Asian economic development. New York: MacMillan, 1998a, pp. 255-79.

"Liberalization, Moral Hazard in 
Banking, and Prudential Regulation: Are Capital Requirements Enough?" Graduate School of Business, Stanford University, Working Paper No. 1466R, 1998b.

Kane, Edward. The S\&L insurance crisis: How did it happen? Washington, DC: Urban Institute Press, 1989.

Keeley, Michael C. "Deposit Insurance, Risk, and Market Power in Banking." American Economic Review, December 1990, 80(5), pp. 1183-200.

Lam, Chun H. and Chen, Andrew H. "Joint Effects of Interest Rate Deregulation and Capital Requirements on Optimal Bank Portfolio Adjustments." Journal of Finance, June 1985, 45(2), pp. 563-75.

Radelet, Steven and Sachs, Jeffrey D. "The East Asian Financial Crisis: Diagnosis, Remedies, Prospects." Brookings Papers on Economic Activity, March 1998, 1, pp. 1-74.

Rochet, Jean-Charles. "Capital Requirements and the Behaviour of Commercial Banks." European Economic Review, June 1992, 36(5), pp. 1137-70.

Rothschild, Michael and Stiglitz, Joseph E. "Equilibrium in Competitive Insurance Markets: An Essay on the Economics of Imperfect Information." Quarterly Journal of Economics, November 1976, 90(4), pp. 619-28.

Shoven, John B.; Smart, Scott B. and Waldfogel, Joel. "Real Interest Rates and the Savings and Loan Crisis: The Moral Hazard Premium."
Journal of Economic Perspectives, Winter 1992, 6(1), pp. 155-67.

Smith, Bruce D. "Private Information, Deposit Interest Rates, and the 'Stability' of the Banking System." Journal of Monetary Economics, June 1984, 14(3), pp. 293-317.

Stiglitz, Joseph E. "Credit Markets and the Control of Capital." Journal of Money, Credit and Banking, May 1985, 17(2), pp. 133-52. . "Introduction-S\&L Bail-Out," in J. R. Barth and R. D. Brumbaugh, eds., The reform of the Federal Deposit Insurance: Disciplining the government and protecting the taxpayers. New York: Harper Collins, 1992, pp. 20-35.

."The Role of the State in Financial Markets," in Michael Bruno and Boris Pleskovic, eds., Proceedings of the World Bank Annual Conference on Development Economics, 1993. Washington, DC: World Bank, 1994, pp. 19-52.

Suzuki, Yoshio. The Japanese financial system. Oxford: Clarendon, 1987.

Tobin, James. "Asian Financial Crisis." Japan and the World Economy, July 1998, 10(3), pp. 351-53.

Weisbrod, Steven R.; Lee, Howard and RojasSuarez, Liliana. "Bank Risk and the Declining Franchise Value of the Banking Systems in the United States and Japan.” International Monetary Fund (Washington, DC) Working Paper No. 92-45, June 1992. 
Copyright of American Economic Review is the property of American Economic Association. The copyright in an individual article may be maintained by the author in certain cases. Content may not be copied or emailed to multiple sites or posted to a listserv without the copyright holder's express written permission. However, users may print, download, or email articles for individual use. 